NBER WORKING PAPER SERIES

\title{
FACTOR UTILIZATION IN INDIAN MANUFACTURING: A LOOK AT THE WORLD BANK INVESTMENT CLIMATE SURVEYS DATA
}

\author{
Ana M. Fernandes \\ Ariel Pakes \\ Working Paper 14178 \\ http://www.nber.org/papers/w14178
NATIONAL BUREAU OF ECONOMIC RESEARCH
1050 Massachusetts Avenue
Cambridge, MA 02138 \\ July 2008
}

This paper builds on a chapter by the same authors entitled "Evidence of Underemployment of Labor and Capital in Indian Manufacturing" included in the World Bank South Asia Region report Accelerating Growth and Job Creation in South Asia. The findings expressed in this paper are those of the authors and do not necessarily represent the views of the World Bank. The views expressed herein are those of the author(s) and do not necessarily reflect the views of the National Bureau of Economic Research.

NBER working papers are circulated for discussion and comment purposes. They have not been peerreviewed or been subject to the review by the NBER Board of Directors that accompanies official NBER publications.

(C) 2008 by Ana M. Fernandes and Ariel Pakes. All rights reserved. Short sections of text, not to exceed two paragraphs, may be quoted without explicit permission provided that full credit, including $\odot$ notice, is given to the source. 
Factor Utilization in Indian Manufacturing: A Look at the World Bank Investment Climate Surveys Data

Ana M. Fernandes and Ariel Pakes

NBER Working Paper No. 14178

July 2008

JEL No. L11,L5,O4,O53

\title{
ABSTRACT
}

We use the World Bank Investment Climate Surveys data to analyze the employment of both labor and capital in Indian manufacturing. We focus on disparities among states in manufacturing employment patterns, and provide reduced form evidence of their relationship to both (i) institutional constraints, and (ii) productivity.

\author{
Ana M. Fernandes \\ Development Research Group \\ The World Bank \\ 1818 H Street, N.W. \\ Washington, D.C. 20433 \\ afernandes@worldbank.org \\ Ariel Pakes \\ Department of Economics \\ Harvard University \\ Littauer Room 117 \\ Cambridge, MA 02138 \\ and NBER \\ ariel@ariel.fas.harvard.edu
}




\section{Introduction.}

There has been some concern with the lack of growth, particularly of employment growth, in Indian manufacturing, and its relationship to various institutional constraints. Partly this is a result of the fact that the Indian manufacturing sector is much smaller than that sector in other economies of similar size. Table 1 illustrates this fact. It indicates that the manufacturing share of value added in India is smaller than that share in other large developing economies, though it is similar to that share in smaller countries with GDP per capita similar to that of India (Pakistan and Vietnam). However as Table 2 shows, the growth rate of value added in manufacturing in India is noticeably lower than that in these smaller similar income countries. Indeed the sectoral growth rate comparisons in Table 2 are rather striking. The growth rate of value added in services in India is comparable to that in China, and about 10 percentage points higher than that in any other country in our list. In rather stark contrast the growth rate of value added in manufacturing in India is only about a half that in China and Vietnam, and quite a bit lower than that in Pakistan.

Why is the relative performance of the Indian manufacturing sector, relative both to the service sector and to the manufacturing sectors in other comparable countries, so poor and what are its implications for employment and income distribution in India? This paper uses the World Bank Investment Climate Surveys to examine a component of this question. In particular we analyze the labor and capital employment rates of Indian manufacturing firms and their relationship to productivity and various institutional constraints.

Several researchers have argued that the restrictiveness of labor market regulations in India is one of the most important constraints on the performance of its manufacturing sector. Our analysis focuses exclusively on the formal (organized) manufacturing sector in India for which data is available and to which labor market regulations are applicable. ${ }^{1}$

\footnotetext{
${ }^{1}$ Indeed recent data from the ILO and OECD (2007) suggest that overall employment growth in India between 2000 and 3005 was a quite rapid $2.8 \%$ per annum (compared to only $1 \%$ in China). However the OECD (2007) also reports that close to $90 \%$ of the population employed in India work in the informal sector (versus only $50 \%$ in China), and there is some indication that the recent strong job creation in India has
} 
Labor market regulations are described in detail in Ahsan and Pages (2005) and in World Bank (2006). Here we only point out the most controversial of those regulations: the 1982 amendment to the Industrial Disputes Act (IDA) of 1947 which made the firing of workers illegal for firms employing more than 100 workers except with previous permission from the appropriate state government.

The evidence indicates that the permission to fire workers is rarely granted (see Ahsan and Pages, 2005). Early work by Fallon and Lucas (1991) found that the introduction of employment laws restricting the firing of workers in India led to a substantial decline in the demand for labor by manufacturing industries. Hence, the objective of the regulations - to protect jobs - resulted in fewer jobs being created. More recently, Besley and Burgess (2004) find that Indian states which amended labor market regulations to make them more restrictive (i.e., to give greater protection to workers) experience lower output, lower employment, lower investment, and lower productivity in the manufacturing sector. Ahsan and Pages (2005) also find important employment losses in Indian manufacturing as a result of restrictive regulations on the firing of workers, particularly in labor-intensive industries such as textiles.

In this paper we ask whether factor employment in manufacturing firms in India is "abnormally" low or "abnormally" high conditional on: (i) firm productivity, (ii) the amount of other factors employed by firms, and (iii) the factor costs faced by firms. With respect to labor our measure of "abnormal" is constructed as the ratio of (1) the labor employment that would be optimal for the firm if there were no hiring and firing costs (or constraints), and (2) the firm's actual employment of labor. That is, if our measure, which we will call "underutilization of labor", for a firm equals x then a firm without hiring and firing costs that had the same productivity, capital and factor costs as the given firm would increase its demand for labor relative to the given firm by a factor of $\mathrm{x}$. To get a different perspective been mostly "bad" jobs i.e., those in the informal sector. For example the OECD (2007) report estimates that growth in formal employment in urban China is much higher than growth in formal employment in urban India in the same period (3.1\% versus $1.7 \%)$. 
on the implications of the empirical magnitudes obtained we also compute the percentage difference between the actual cost of labor and the cost of labor that would make a firm without hiring and firing costs just satisfied with its current labor employment.

We then look at differences in our underutilization of labor measure across Indian states, and at the relationship between our underutilization of labor measures and measures of productivity, underutilization of capital (described below), and data on institutional constraints to doing business collected by the World Bank Investment Climate Surveys. We find very large differences in the extent of underutilization of labor across Indian states. Although it is probably impossible to eliminate all the employment constraints faced by Indian manufacturing firms, we might think it is possible that the states with "poorly functioning" labor markets, that is states with large underutilization of labor, could, with institutional improvements, approach the figures for underutilization of labor in those states with better functioning markets. We delve deeper into the meaning of the expression "poorly functioning" in the last part of the paper where we summarize the relationship between our underutilization figures and other characteristics of the firm and the states it operates in.

We want to be clear at the outset that our underutilization figures should not be taken as literal predictions of what would happen to the manufacturing demand for labor were policy-makers to eliminate all hiring and firing costs in a given state. This because were policy-makers to eliminate these costs and constraints for all firms in a state and the firms began to respond by employing more labor, the cost of labor would likely rise, and the output price would likely fall below what our current estimates predict (the current estimates do not account for the impact of an increase of a firm's competitors quantities on the firm's own sales). These two processes would decrease the firm's marginal revenue product for labor and hence their incentive to hire more workers. For precise predictions of what would happen to employment patterns in a state where labor market institutions would be improved, we would need to analyze a general equilibrium model which endogenized both the wage rate and the output prices of firms in the manufacturing sector. Developing such a model is left for future research.

This paper also considers an analogous measure of "underutilization" of capital. This 
measure is constructed as the ratio of: (1) the optimal capital for the firm if there were perfect rental markets for capital goods, and (2) the firm's actual capital stock. The perfect rental markets concept is quite abstract; it assumes that firms could rent each different kind of capital good at an annual rental cost equal to the sum of the current rate of interest on loans to manufacturing firms plus the depreciation rate on those capital goods. Still our results on capital are both comforting in that they correspond to our intuitions on the capital market, and surprising in how different they are from our labor underutilization patterns.

In particular there is evidence that capital markets are much better at arbitraging differences across states than labor markets. First, the differences in both the cost of capital and the underutilization of capital across states are noticeably smaller than the differences in both labor costs and the underutilization of labor across states and the magnitudes are striking. The interstate variance in the percentage underutilization of labor is about three and a half times the interstate variance in the percentage underutilization of capital. Second, though we obtain large positive numbers for the underutilization of labor, that is labor is "underutilized" compared to what would happen if there were no hiring and firing costs or constraints, the numbers for the underutilization of capital are negative. That is, given the amount of labor employed by firms, firm productivity, and cost of capital, firms are employing more capital than they would employ if they were facing perfect rental markets for capital goods.

Of course the overutilization of capital may just be a response to the fact that firms are underutilizing labor. That is, firms which face many constraints in the hiring and firing of workers may respond by increasing their use of capital relative to labor. Indeed, as we show below, firms which underutilize labor disproportionately tend to overutilize capital disproportionately. Moreover it is clear that if labor employment were to rise, say in response to an improvement in labor market institutions, the marginal revenue product of the capital in place would rise, and our measure of the overutilization of capital would fall. Moreover the overutilization of capital figures that we obtain are much smaller in magnitude than the underutilization of labor figures. Consequently, improvements in labor market regulations that may be feasible may well also eliminate the overutilization of capital. Unfortunately to 
answer whether this is likely to be true we would require a more detailed general equilibrium model alluded to above.

The last section of this paper investigates the reduced form relationships (i) among our measures of underutilization of labor, underutilization of capital, and productivity, and (ii) between these three measures and answers to questions posed on the investment climate survey. Perhaps the most striking finding of this analysis is that the extent of underutilization of labor by a firm is strongly and positively related to the firm's productivity. The more productive firms also tend to overutilize capital somewhat more than the average, though not to the same extent that they underutilize labor. The results in prior sections indicated that liberalizing the labor market in states where there is high underutilization of labor is likely to result in significant increases in both labor demand and wages in those states. The results in the last section give us reason to believe that a lowering of labor market constraints would also increase productivity, and it would do so without significant increases in the demand for capital. We should expect an increase in productivity both because the more productive firms are likely to increase their output disproportionately, and because each firm's productivity should increase as labor and capital employment move towards their efficient levels.

Other relevant reduced form findings include the following: (i) firms which suffer more production losses due to electricity outages are less productive than the average firm in their states, and firms in states in which the average production losses due to outages are high underutilize labor and capital more than firms in states with less frequent outages, (ii) firms reporting more problems with corruption are the more productive firms in the state and they have relatively high underutilization of both factors of production, (ii) within states, it is the relatively more productive firms that are more likely to receive loans, suggesting that the loan-granting institutions are able to select out the more productive firms, and (iv) states in which a disproportionate number of firms received loans are the states with less underutilization of both factors of production, particularly of capital.

The remainder of the paper proceeds as follows. Section 2 describes the data and Section 3 describes the computation of the underutilization measures. Sections 4 and 5 analyze the underutilization of labor and capital, respectively. Section 6 analyzes productivity. Section 
7 discusses the relationships between underutilization of labor and capital, productivity, and investment climate variables. Section 8 concludes.

\section{Data.}

Our analysis requires the use of data on factors of production and sales for manufacturing firms in India. Our data is taken from the Investment Climate Surveys conducted in India jointly by the World Bank and the Confederation of Indian Industry in two rounds: 2002 and 2005. The surveys cover formal manufacturing firms across 12 Indian states and 7 industries based on a random sample designed to be representative of the population of firms according to their industry and location. ${ }^{2}$ The surveys provide information on firm characteristics, investment climate variables, and accounting variables. Accounting variables were collected for the two years immediately preceding the administration of the two survey rounds (2001 and 2004) as well as for prior years through retrospective questions. To avoid measurement problems associated with retrospective data, we use only the accounting variables for 2001 and 2004. The 2005 survey round covered all firms from the 2002 survey round that were still in business and willing to respond to the questionnaire as well as additional firms not covered in the 2002 survey round. Appendix A provides more details on the data and shows some descriptive statistics for the sample.

\section{Ingredients for the Underutilization Measures:}

\section{Production Functions and Factor Costs.}

In order to obtain our measures of the underutilization of labor (capital) we need to know what labor (capital) employment would be for a firm facing no hiring and firing costs or constraints (perfect rental markets for capital goods). For this purpose we use:

\footnotetext{
${ }^{2}$ For simplicity, we refer to the units in our analysis as firms, but the surveys cover establishments.
} 
- estimates of a production function, or more precisely of a "sales generating" function,

- estimates of the cost of employing labor (capital).

The availability of a sales generating function enables the calculation of the increment in sales for a unit increase of employment at different employment levels for each firm. The labor that the firm would employ if there were no hiring and firing costs or constraints is obtained as the labor employment level that would set the firm's increment in sales due to a new worker exactly equal to the cost of employing that worker. An increment in labor employment above this "statically optimal" level would generate more labor costs than sales, and a labor employment level below this static optimum would mean that the firm would increase sales more than costs if it increased its number of workers. Our estimates of underutilization of capital are obtained analogously based on the cost of capital.

\subsection{Sales Generating Functions.}

The term "sales generating" function was introduced by Olley and Pakes (1996) to emphasize that the fact that they were analyzing the relationship between sales (deflated by a producer price index) and the inputs that went into producing those sales, rather than the relationship between physical quantities of outputs and inputs as in a production function. When working with sales data from homogenous product industries, we can insure that we are analyzing the determinants of the physical quantity of output by allowing for industry specific multiplicative constant terms, which account for inter-industry price differences. Though in our analysis we allow for a separate multiplicative constant for the 7 different industries, the homogenous product paradigm is a stretch for our data. In fact, the dependent variable used in our analysis is the sales generated by a firm operating in a differentiated product industry.

This leaves us with the question of whether the relationship that we are estimating has a natural interpretation, and if that interpretation has consequences for the choice of estimation procedure or for subsequent use of the estimates. We will assume that each 
firm's demand curve has a constant elasticity conditional on the output (or prices) of the other firms, and that the production function is Cobb-Douglas. Then there is a log-log relationship between sales and inputs, just as there is a log-log relationship between output and inputs in the Cobb-Douglas production function case, but now the objects in that log-log relationship have a slightly different interpretation. Differences in productivity in generating sales will reflect the sum of differences in the location of demand curves and differences in the ability to transform inputs into physical output. The input coefficients estimated from the sales generating function will reflect the physical production function coefficients divided by one minus the inverse elasticity of demand. As a result, (i) whenever we consider counterfactuals which change the output of competing firms, we should expect each firm's "sales productivity" to change, and (ii) we should be careful not to interpret our estimates of returns to scale as scale effects in the production of physical output.

We will use our sales generating function estimates in two ways: (1) to construct the distribution of firm productivity in producing sales, and (2) to measure the excess demand (supply) for labor and/or capital at the going wage (rental) rate. The measure of firm productivity is sales divided by an index of inputs. We need the sales generating function estimates to obtain the weights used to construct the index of inputs. Our measure of excess demand (supply) is the number of units of labor (capital) that a firm would have to hire before the marginal revenue product of labor (capital) would equal the going wage (rental) rate. The marginal revenue product schedule is the derivative of the sales generating function with respect to the input, and hence also requires estimates of the sales generating function. Subsequent sections of the paper address the substantive implications of our productivity and excess demand measures.

The correct way to obtain sales generating function estimates depends on the appropriate model for input demand and for firm exit. This because the residual in the sales equation is productivity, and firms' input and exit decisions will depend on their productivity. As a result both an endogeneity and a selection issue must be accounted for before one can obtain reliable estimates. The endogeneity issue is that the residual in the equation of interest is correlated with the variables (the inputs) on the right hand side of that equation. The 
selection issue is that small firms (firms with a low capital stock or other sunk investments) continue (do not exit) only if their productivity is quite large, while large firms will continue even with lower productivity. As a result, the distribution of productivity of the firms that survive, and hence are included in the data on transitions in productivity, is not independent of the quantity of capital.

The next subsection describes our estimation procedure. The reader who is not interested in the technical details of how the estimates are obtained should be able to skip this section and still understand the remainder of the paper.

\subsubsection{Estimation Procedure.}

We now describe how we obtained the sales generating function estimates. The basic framework for estimation is taken from Olley and Pakes (1996), but we modified their estimation techniques to account for special features of the institutional setting in Indian manufacturing, as explained below. ${ }^{3}$

Let $\left(y_{j, t}, l_{j, t}, k_{j, t}, i_{j, t}, z_{j, t}\right)$ be value added (sales minus material inputs), labor, capital, investment, and temporary labor for firm $j$ in year $t$. All of these variables, except investment, are in logs. Temporary labor is defined as all (paid) short-term (i.e., for less than a year) employees with no guarantee of renewal of employment contract, while permanent labor is defined as all paid workers that are not temporary. Our sales generating function is given by:

$$
y_{j, t}=\beta_{l} l_{j, t}+\beta_{k} k_{j, t}+\beta_{z} z_{j, t}+\omega_{j, t}+\eta_{j, t},
$$

where we have written the disturbance as a sum of $\omega_{j, t}$ and $\eta_{j, t} \cdot \omega_{j, t}$ is defined to be the productivity that the firm expects for the period given its information at the time when investment decisions are made (which we take to be the beginning of the period). $\eta_{j, t}$ is defined to be the difference between the actual realization of the productivity term and the

\footnotetext{
${ }^{3}$ See part 2 of Ackerberg, Benkard, Berry, and Pakes (2007) for a more in-depth discussion of why and how one might want to modify the framework in Olley and Pakes (1996).
} 
firm's expectation. If there is measurement error in sales it will also be included in $\eta_{j, t}$.

Our goal is to obtain estimates of the coefficients $\left(\beta_{l}, \beta_{k}, \beta_{z}\right)$ with desirable properties. The problem is that due to the selection and endogeneity problems, standard estimators for those coefficients - including OLS, fixed effects, and instrumental variables - will produce inconsistent estimates of these parameters. In particular, (i) the distribution of the $\omega_{j, t}$ which we observe has been truncated by an exit decision whose truncation point depends on the right-hand side variables, and (ii) since the productivities in the truncated distribution are known to the firm at the beginning of the period and correlated over time, any reasonable model for input choice will result in those productivities being correlated with the firm's labor and capital inputs.

Since $\omega_{j, t}$ is defined to be the expected productivity at the time when the investment decision is made, Olley and Pakes (1996) show that the investment function $\left(i_{j, t}\right)$ can be written as a function of $\omega_{j, t}$ and other "dynamic factors". Dynamic factors are the factors of production which the firm finds costly to adjust over the period between investment decisions, so that past levels of one of those factors affect the current employment of that factor independently of current cost and demand conditions. In Industrial Organization terminology, dynamic factors are "state" variables in the dynamic problem that leads to the firm's investment choices. Olley and Pakes assume that labor is not a dynamic factor (i.e., labor can be adjusted optimally in every period). However, given the structure of the labor laws in India, we shall also try specifications where labor is considered a dynamic factor. Since we try different specifications where the set of factors which are dynamic varies, we change our notation slightly here and let $x^{d}$ denote the list of dynamic factors and $x^{s}$ be a list of the static factors (i.e., those factors of production which can be adjusted optimally in every period).

Our investment function then becomes:

$$
i_{j, t}=i_{t}\left(\omega_{j, t}, x_{j, t}^{d}\right)
$$

where $x_{j, t}^{d}$ is a vector of dynamic factors. The function $i_{t}(\cdot)$ differs across periods because it depends on the state variables of competing firms, and the list of state variables in a given 
industry varies over time. Provided that $i_{j, t}>0$, this function has an inverse which is given by:

$$
\omega_{j, t}=i_{t}^{-1}\left(i_{j, t} ; x_{j, t}^{d}\right) \equiv h_{t}\left(i_{j, t} ; x_{j, t}^{d}\right)
$$

Substituting equation (1) into the sales generating function, using the new notation for the inputs, and rearranging we have:

$$
y_{j, t}=\beta_{x}^{s} x_{j, t}^{s}+\phi_{t}\left(i_{j, t} ; x_{j, t}^{d}\right)+\eta_{j, t}
$$

where

$$
\phi_{t}\left(i_{j, t} ; x_{j, t}^{d}\right) \equiv \beta_{x}^{d} x_{j, t}^{d}+h_{t}\left(i_{j, t} ; x_{j, t}^{d}\right)
$$

and $\left(\beta_{x}^{s}, \beta_{x}^{d}\right)$ are the coefficients of the static and dynamic inputs, respectively.

If $\left(x_{j, t}^{d}, x_{j, t}^{s}\right)$ cannot respond to movements in $\eta_{j, t}$, that is if those factors of production cannot respond to changes in productivity that occur between the time when investment is made and the time when production occurs, then equation (??) can be estimated by ordinary least squares (OLS) using a polynomial (or any other sufficiently rich non-parametric function) to approximate $\phi\left(i_{j, t} ; x_{j, t}^{d}\right)$. If not, then equation (??) can be estimated by instrumental variables using lagged values of the production factors that are correlated with $\eta_{j, t}$ as instruments. Olley and Pakes (1996) assume that none of the production factors can adjust to realizations of $\eta_{j, t}$, but we will try alternative possibilities, as shown below. Let $\left(\hat{\beta}_{x}^{s}, \hat{\phi}_{j, t}\right)$ be the estimates obtained in this manner.

We still require estimates of $\beta_{x}^{d}$. To obtain these estimates, we need to account for selection bias and this, in turn, requires a model for the exit decision. We let $\chi_{t+1}=1$ indicate the firm continues and $\chi_{t+1}=0$ indicate exit. Olley and Pakes show that provided $\left\{\omega_{j, t}\right\}$ evolves as a Markov Process, the exit decision can be written as: ${ }^{4}$

\footnotetext{
${ }^{4}$ More precisely, we treat $\left\{\omega_{j, t}\right\}$ as a univariate Markov Process. This is where our assumptions are likely at odds with our model of a sales generating function from a differentiated product market. If $\omega_{j, t}$ includes a term which reflects the location of the individual firm's demand curve (as well as a term that reflects its physical productivity), then the assumption that the firm's own physical productivity evolves as a Markov process does not guarantee that $\omega_{j, t}$ evolves as a Markov process. For now, we simply treat the Markov
} 


$$
\chi_{t+1}=1 \Leftrightarrow \omega_{j, t+1} \geq \underline{\omega}_{t+1}\left(x_{j, t}^{d}\right) .
$$

So the probability of survival conditional on information available at time $t$ is given by:

$$
\operatorname{Pr}\left(\chi_{j, t+1}=1 \mid \underline{\omega}_{t+1}\left(x_{j, t}^{d}\right), \omega_{j, t}\right)=F\left(\underline{\omega}_{t+1}\left(x_{j, t}^{d}\right), \omega_{j, t}\right)
$$

where $F(\cdot)$ is a distribution function. Note that, for any given $\omega$, the function $F(\cdot)$ is monotone decreasing in $\underline{\omega}(\cdot)$, so for fixed $\omega$ we can invert this equation and write:

$$
\underline{\omega}_{t+1}(\cdot)=F^{-1}\left(F\left(\underline{\omega}_{t+1}(\cdot) ; \omega\right)\right) .
$$

We will use this fact below.

From equation (1), $\omega_{j, t}=h_{t}\left(i_{j, t}, x_{j, t}^{d}\right)$. Substituting this into equation (3) shows that our survival equation can be estimated as:

$$
\operatorname{Pr}\left(\chi_{j, t+1}=1 \mid \underline{\omega}_{t+1}\left(x_{j, t}^{d}\right), \omega_{j, t}\right)=F\left(\underline{\omega}_{t+1}\left(x_{j, t}^{d}\right), h_{t}\left(i_{j, t}, x_{j, t}^{d}\right)\right) \equiv \tilde{F}\left(x_{j, t}^{d}, i_{j, t}\right)
$$

using a sufficiently rich functional form for $\tilde{F}(\cdot)$. Letting $\mathcal{F}_{j, t} \equiv \tilde{F}\left(x_{j, t}^{d}, i_{j, t}\right)$, we have:

$$
\underline{\omega}_{t+1}(\cdot)=\tilde{F}^{-1}\left(\mathcal{F}_{j, t}\right) .
$$

We can now return to the issue of estimating $\beta_{x}^{d}$. Consider period $t+1$. We only observe $\omega_{j, t+1}$ if the firm survives and our expectation for $\omega_{j, t+1}$ conditional on survival is given by:

$$
\begin{gathered}
E\left[\omega_{j, t+1} \mid \omega_{j, t}, \chi_{t+1}=1\right]=\int_{\underline{\omega}_{j, t+1}\left(x_{j, t+1}^{d}\right)} p\left(\omega_{j, t+1} \mid \omega_{j, t}\right) \equiv g\left(\underline{\omega}_{j, t+1}\left(x_{j, t+1}^{d}\right), \omega_{j, t}\right) \\
=g\left(\phi_{t}\left(i_{j, t}, x_{j, t}^{d}\right)-\beta_{x}^{d} x_{j, t}^{d}, \tilde{F}^{-1}\left(\mathcal{F}_{j, t}\right)\right)+\xi_{j, t+1} \\
\equiv \tilde{g}\left(\phi_{t}\left(i_{j, t}, x_{j, t}^{d}\right)-\beta_{x}^{d} x_{j, t}^{d}, \mathcal{F}_{j, t}\right)+\xi_{j, t+1},
\end{gathered}
$$

where the first equality uses equations (1) and (4), the last equation defines $\tilde{g}(\cdot)$, and

$$
\xi_{j, t+1} \equiv \omega_{j, t+1}-E\left[\omega_{j, t+1} \mid \omega_{j, t}, \chi_{t+1}=1\right] .
$$

assumption as a convenient approximation to a more complicated process, an approximation which has done well in past uses of the technique. 
Consequently,

$$
y_{j, t+1}-\beta_{x}^{s} x_{j, t+1}=\beta^{d} x_{j, t+1}^{d}+\tilde{g}\left(\phi_{t}\left(i_{j, t}, x_{j, t}^{d}\right)-\beta_{x}^{d} x_{j, t}^{d}, \mathcal{F}_{j, t}\right)+\xi_{j, t+1}+\eta_{j, t+1} .
$$

This equation can be consistently estimated by substituting our consistent estimates of $\left(\beta_{x}^{s}, \mathcal{F}_{j, t}, \phi_{t}(\cdot)\right)$ for their true values and approximating $\tilde{g}(\cdot)$ with a sufficiently rich nonparametric function. If any of the $x^{d}$ can respond to realizations of $\xi$ or $\eta$ then lagged values of those variables must be used in forming the moments to be used in the estimation.

\subsubsection{Estimation Results.}

The sales generating function estimates we report combine survey data for Indian manufacturing firms in all 7 industries (listed in Appendix A) but allow for industry specific average levels of (the log of) productivity. While we attempted to estimate a sales generating function for each industry separately, the data was not rich enough to determine industry differences in input coefficients in a reliable way. Table 3 presents a selection of our results in two panels. Panel A does not allow the sales generating function coefficients to differ by firm size, while Panel B allows small firms, defined as those with less than 50 employees, to have different coefficients relative to large firms. Since we will investigate later in the paper differences in productivity by firm size, we wanted to ensure that any differences we find then were not simply a result of firms below a certain size cutoff being engaged in activities that were different enough to warrant different sales generating function coefficients. The estimation of different coefficients across firm size also accommodates a special feature of the Indian manufacturing sector which is its inclusion of a much larger share of relatively small firms than the manufacturing sectors in other economies. This is illustrated in Figure 1 which compares the size distribution of firms in India to that in China, Brazil, and Indonesia, based on data from Investment Climate Surveys. When examining whether there were differences in sales generating function coefficients by firm size, we found that the largest differences occurred for the 50 employee cutoff reported in Table 3.

We will focus on the estimates that allow for different coefficients across small and large firms (Panel B) as Table 3 provides some evidence that such differences exist, particularly 
in the labor and temporary labor coefficients. Columns 1 and 2 show the OLS estimates for the full sample and for the subsample of observations for which investment differs from zero, respectively. As discussed in the previous subsection, to obtain our sales generating function estimates we can only use observations with positive investment, as it is only then that the investment can be used to help control for prior values of productivity which must be controlled for in order to get unbiased estimates of the coefficients of interest.

Columns 3 and 4 show the standard Olley and Pakes estimators. Column 3 shows estimates that control only for the endogeneity of input choices, while the estimates in column 4 control also for the selection bias induced by exit. In moving from Column 2 to column 3 , we are controlling for the fact that the capital and labor inputs are likely to be positively correlated with the residual (which, recall, includes productivity). Thus, we expect to see a fall in input coefficients, which we do, and a fall in the estimate of "returns to scale", in this case one which is reasonably dramatic. As explained earlier, the fact that larger firms will continue in operation with lower values of productivity than smaller firms induces a negative correlation between capital and the residual in the estimates in column 3. Therefore, when we move from column 3 to column 4 we expect to see an increase in the capital coefficients, which again is reasonably dramatic. These results are similar to those found in Olley and Pakes (1996).

Columns 5 and 6 differ from prior results, including those in columns 3 and 4 , by allowing labor to not be fully adjustable in the short run. These specifications accommodate a special feature of the Indian manufacturing sector which are the stringent labor market regulations it faces. Thus, hiring and firing costs for labor cannot be taken to be negligible as in the earlier production function estimation literature which assumed that labor can be optimized in the short-run. If labor is partially fixed, then the results in columns 3 and 4 combine the impact of the quantity of labor in place on investment for a given capital stock - an effect that we would expect to be positive - with the effect of labor on output conditional on capital (with the sales generating function coefficient of interest). Accordingly, we would expect the labor coefficient estimates in columns 5 and 6 to be smaller than those in columns 3 and 4. Again we get quite a striking effect providing evidence that in Indian manufacturing we 
should think of labor as not being freely adjustable in the short run. Note also that allowing labor to be partially fixed brings down the estimates of the "returns to scale" noticeably.

We note that none of these estimates allow either temporary or permanent labor to adjust to the shocks in productivity that occur during the period. We did some investigation of this possibility, but the specifications in columns 5 and 6 seem to be as rich a specification as our data can support. That is, further refinements resulted in large increases in standard errors, and no significant differences in coefficients from those reported above.

\subsection{Factor Costs: Labor.}

We begin by discussing labor costs. The immobility of labor across states could enable interstate differences in labor costs to develop. Also, our analysis treats permanent labor as a homogenous product. Unfortunately, information on schooling that would allow us to differentiate workers in our analysis was not consistently available. As a result our underutilization of labor estimates should probably be interpreted as underutilization of labor for the same mix of workers as the firms are currently employing. However if some types of workers contribute more to the firm's output than others, and there are systematically different fractions of different types of workers in different industries, then this would imply that we should allow for different costs of labor in different industries.

To determine whether we should allow the costs of labor to vary by industry or by state we estimated a regression of average wages from our survey on industry and state dummies. The industry dummies were neither jointly nor individually significant, whereas many of the state dummies were significant. Consequently, we allowed for differences in labor costs across states but not across industries. Table 3 provides the state level average wages from the Indian Annual Survey of Industries (ASI) using the most inclusive definition of wage in that survey, and compares them to the average wages in our survey. We use the ASI wages in what follows since the ASI sample is more representative than our sample, and because for the vast majority of states ASI wages are higher than the average wages from our survey. Hence, by using the ASI wages we will, if anything, underestimate the extent of 
labor underutilization.

\subsection{Factor Costs: Capital.}

Table 4 shows the state level averages of our measures of the components of the cost of capital. The Indian ASI contains measures of average interest rates on loans and average depreciation rates of capital. Our cost of capital measure is the sum of these two averages. Our surveys provide a measure of the interest rate on loans. The mean and median of this measure for each state are shown in the last two columns of the table, and they are quite similar to the interest rates from the Indian ASI.

Note that there is much less variance in the cost of capital across states than there is in the cost of labor. The coefficient of variation of the cost of capital across states is only half that of wages (15 and 14\% in 2001 and 2004, versus 28 and 30\%, respectively). We also regressed the average interest rate of loans from our survey on industry and state dummies. The industry nor the state dummies were neither jointly nor individually significant. Recall that the state dummies were significant in the wage regression. This difference suggests that capital markets in India are able to arbitrage interstate differences in the returns to capital reasonably effectively while labor markets and labor flows are much less able to arbitrage interstate differences in the returns to labor. Still for consistency with the labor results we use the cost of capital from the ASI and allow it to vary across states in the calculations that follow.

\section{Underutilization of Labor.}

The most striking result that we obtain is the extent of underutilization of labor across manufacturing firms in India. Overall we estimate underutilization of 5.8 times current manufacturing employment in 2001, and 3.4 times in 2004. Further underutilization is estimated to be large and positive for every size group of firms (see Figure 2) and every state (see Table 5) in India. 
The extent of underutilization of labor varies dramatically across states. Higher GDP per capita states have less underutilization. A similar correlation is evident in the time series dimension. Table 6 and Figure 3 compare the changes in underutilization of labor by state to the changes in GDP per capita by state between 2001 and 2004 across states. Again there is a striking negative correlation. Indeed if we omit one outlier, West Bengal (which exhibits a very large decline in the underutilization of labor), the data look like they were generated by a simple linear model. That is high GDP per capita states exhibit less underutilization of labor, and states where underutilization is falling are states whose per capita GDP is rising. Uttar Pradesh has the lowest GDP per capita and the second lowest growth rate in GDP per capita, and hence is considered a "lagging region". It has both the highest percentage underutilization of labor and the highest growth rate in that percentage (indeed it is one of the few states where underutilization is in fact growing).

To put these figures in a different light we calculated what the wage would have had to be for the firm's current employment to be "statically optimal" (i.e., the wage equal to the firm's marginal revenue product of labor at its current employment level). Across manufacturing firms this wage averaged 6.8 times the current wage rates in 2001 and 4.6 times the current wage rates in 2004. Moreover in the three states with highest underutilization of labor - Uttar Pradesh, Madhya Pradesh, and West Bengal - this wage averaged about 9 times the actual wage in the state, a number which is probably larger than the average tenure of a manufacturing worker. In contrast in Delhi, which was the state with the lowest underutilization of labor, the wage averaged about $20 \%$ of a worker's year's wages. If nothing more the large divergence in these numbers across states suggest a role for the impact of differential labor market regulations across states.

The extent of underutilization of labor did decrease significantly between 2001 and 2004 . The decrease in underutilization occurred in all size groups of firms, but it was most pronounced among firms with 50 to 100 workers (see Figure 2). The size cutoff at which firms must start abiding with restrictive employment regulations in most Indian states is 100 workers, so there is some indication that institutional changes have moderated the impact of those regulations during this period. We note that this occurred at the same time as the 
fraction of the manufacturing labor force employed by firms in the 50 to 100 worker group increased, so the fall in underutilization of labor in this group was not a result of this size group discarding a disproportionate number of workers. A related fact is that there was a distinct tendency over this period for manufacturing employment to shift from large firms (with more than 250 workers) to moderately sized firms (with 50 to 250 workers). ${ }^{5}$

\section{Underutilization of Capital.}

The differences between our estimates of the underutilization of capital and that of labor are striking. In particular there is overutilization of capital; i.e., the marginal revenue product of the capital employed at firms tends to be less than the cost of capital. As Table 7 and Figure 4 show, this is true for all size classes of firms and all states in 2001 and in 2004. Indeed the overutilization of capital is, on average, equal to about three quarters of the capital stock.

This magnitude is much smaller than the corresponding magnitudes for the underutilization of labor. To see this in a more intuitive way we calculated what the cost of capital would have had to be for the firm's current capital to be "statically optimal" (i.e., the cost of capital equal to the firm's marginal revenue product of capital at its current capital level). On average this "statically optimal" cost of capital was $58 \%$ of the current cost of capital in 2001 and $64 \%$ in 2004 . These numbers are different from one, but only by about $40 \%$ (recall that the underutilization of labor resulted in ratios of wage rates to marginal productivity of labor of about $600 \%$ ). Moreover, unlike the figures on underutilization of labor, the extent of overutilization of capital did not change much between 2001 and 2004, it does not vary much across states or size groups, and it is not correlated with differences in GDP per capita across states. ${ }^{6}$

\footnotetext{
${ }^{5}$ See Appendix Tables 1 and 2.

${ }^{6}$ Interestingly, we also find evidence of important underutilization of labor and overutilization of capital in another South Asian country with restrictive labor regulations: Sri Lanka. See Appendix B for a discussion of those results.
} 


\section{Manufacturing Productivity.}

While the focus of this paper is not on the determinants of total factor productivity in the Indian manufacturing sector, we are interested in the relationship between our underutilization measures and productivity. Therefore we now discuss one finding on manufacturing productivity that is of interest to the subsequent results. It is presented in Table 8 and the accompanying Figure 5 and Figure 6.

The table and figures show that interstate differences in average manufacturing productivity are not positively correlated with interstate differences in GDP per capita. The precise nature of the relationship between manufacturing productivity and GDP per capita differs

depending on whether we consider a sales share weighted average of firm productivity, or an unweighted average of firm productivity. However it is clear that among all states except the very high GDP per capita states there is a negative relationship between manufacturing productivity and GDP per capita, though the relationship flattens out and may turn positive among the highest GDP per capita states. If states with higher GDP per capita are states in which overall productivity is higher, the higher productivity levels are coming from sectors other than manufacturing (e.g., services).

\section{The Relationships Between Our Underutilization Mea-}

\section{sures, Our Productivity Measures, and Responses to}

\section{the Investment Climate Survey.}

In this section we discuss the findings from a reduced form analysis of the relationships between our firm-level underutilization measures and firm-level productivity, and the relationships between these three variables and the responses to questions in the investment

climate survey. To facilitate the analysis we estimated a three-equation system using our measures of the underutilization of labor, the underutilization of capital, and productivity, 
as dependent variables. The "explanatory" variables are the same in all equations, and they are all based on information from the investment climate surveys. We put the word "explanatory" in quotation marks because we want to emphasize that we make no attempt to infer cause and effect from the estimates. We present them only as correlations that a causal model would have to rationalize. The estimates were obtained using seemingly unrelated regression techniques and are shown in Table 9.

The variables from the investment climate survey included were the fraction of the firm's workforce that is unionized, whether the firm had a loan, production losses at the firm due to electricity outages, an indicator of corruption in inspections, the state-year level averages of these variables among the firms in our data set, and the average share of temporary labor in total employment in the state-year (as an indicator of flexibility of local labor markets). Since for each included firm level variable we include also the state-year level averages of these variables, the effects of the firm level variables should be interpreted as within coefficients; i.e., they provide the impact on the dependent variable of the difference between the right hand side variable and the average of that right hand side variable in the given state-year. ${ }^{7}$

We begin with the coefficients from the equation which has productivity as the left hand side variable, i.e. column 3 in Table 9 . All four of the firm level variables have significant coefficients in this equation. The estimated positive coefficient on the firm level unionization variable indicates that firms with a larger fraction of their labor force unionized are more productive than the average firm in their state. This finding could either be a result of it being easier to unionize in more productive firms, or of unionization increasing productivity. All the coefficients on the state-year level variables are more difficult to interpret as the link between a change in the value of the covariate they are attached to and the firm level outcomes of interest is indirect. Still if there are regional economies to organizing union activities, the fact

\footnotetext{
${ }^{7}$ The "explanatory" variables are described in detail in Appendix Table 5. For the within intepretation see Mundlak (1978) who shows that one can allow for group specific fixed effects in linear equations by including, as additional right hand side variables, the group specific averages of all included right hand side variables.
} 
that the average level of unionization in the state-year is positively related to productivity would reinforce the possibility that unions find it easier to unionize where manufacturing productivity is higher. Note that the results in Table 9 also indicate that states with a higher degree of unionization tend to be states with relatively high underutilization of both capital and labor. Of course this need not be causal; it may be that there are omitted variables that cause underutilization and are correlated with state level unionization.

The relationships between productivity and the other firm specific variables are somewhat easier to interpret. Since our productivity estimates take direct account of the impact of capital on sales, the most obvious interpretation of the positive interaction between productivity and the firm level loan variable is that loan-granting institutions are able to select out the higher productivity firms in a region. In contrast, the corresponding state-year level variable indicates that the states in which a disproportionately high number of firms received loans were states with lower manufacturing productivity. About three quarters of loans granted in India are granted by governmental institutions, so the regional pattern of loans might reflect the goals of those institutions. The states in which a disproportionate share of firms has loans are states in which firms have significantly less underutilization of both labor and capital. We note that this finding is not a result of states with a higher fraction of firms having loans being states which are more developed, at least if we measure development by GDP per capita. We tried adding GDP per capita as a right hand side variable to all equations. None of the results presented in Table 9 changed notably, and the GDP per capita coefficients were all insignificant.

Provided not all production losses due to electricity outages were planned for we would expect the firms within a region that experience a higher fraction of their output lost due to electrical outages to have lower productivity, and this is what the results in Table 9 indeed show. Also provided that average production losses across a state influence a firm's perceptions about its own likely future production losses, we should expect a relationship between the state-year level measure of electricity outages and the employment of inputs that have a sunk component to their cost, and recall that we have found both labor and capital should be treated as inputs with sunk costs in India. As a result the strong positive 
relationship between the state-year level measure of production losses due to outages and both our underutilization measures should not be a surprise either. Interestingly, there is a positive relationship between productivity and the average production losses due to outages across state-years. This finding suggests that states where manufacturing is productive are the states which are pushing the boundaries of current electricity generating capacity.

The firm level corruption variable has a positive coefficient in the productivity equation, a finding that might reflect the possibility that it is the more productive firms that are most averse to corruption and therefore most likely to complain about it. The firm and state level coefficients on corruption in the utilization equations are opposite in sign. Firms which complain about corruption tend to employ less labor and capital, ceteris paribus, than other firms in the region. On the other hand the average number of complaints about corruption is higher in states with less underutilization of labor and capital.

None of the other firm level variables exhibit a significant relationship to either underutilization variable. Indeed the most striking information on the underutilization variables is contained in the residuals. Note first that the residual variance in both the underutilization regressions is about $98 \%$ of the total variance, and about $97 \%$ of that variance is within state variance. Given this, the residual covariances imply that the variable most closely related to underutilization of labor in our data is firm level productivity. That is the more productive firms in a region are holding back on hiring relatively more than less productive firms in the same region. Consequently if we were able to institute changes in labor regulations which resulted in all firms hiring labor up to the point where the marginal revenue product of labor equaled the wage we would not only increase employment, we would likely also redistribute output in a way that would increase overall productivity.

Interestingly the residuals also indicate that the more productive firms do not hold back on investment more than less productive firms; if anything they utilize relatively more capital. This finding, taken together with the negative correlation between the underutilization of labor and capital residuals, suggests that one effect of the labor regulations in India might be to induce firms, especially more productive firms, to substitute capital for labor. 


\section{Conclusion}

This paper uses the World Bank Investment Climate Surveys to examine the labor and capital employment rates of Indian formal manufacturing firms and their relationship to productivity and investment climate variables. We are motivated by our desire to understand the factors underlying the relatively weak performance of the Indian formal manufacturing sector; relative to either the Indian services sector or to manufacturing sectors in similarly countries (e.g., China). We define measures of underutilization of labor for Indian firms as the ratio of (1) the labor employment that firms would optimally choose if there were no hiring and firing costs at current wage costs, and (2) firms' actual employment of labor. Analogously, we construct measures of underutilization of capital for Indian firms.

We find that labor is underutilized in manufacturing firms operating in all states. That is, given the amount of capital used by firms, their productivity, and the cost of labor, firms are employing less labor than they would employ if they faced no hiring and firing costs. The extent of underutilization of labor differs substantially across Indian states. In particular, states with higher GDP per capita exhibit much less underutilization of labor. In contrast, our results show overutilization of capital in Indian firms, though the extent of overutilization of capital is much smaller than the extent of underutilization of labor and does not vary a great deal across states. The overutilization of capital may be a response to the underutilization of labor as firms and states which underutilize labor disproportionately also overutilize capital disproportionately.

The most striking finding from our analysis of the relationships between the underutilization of labor, the underutilization of capital, and productivity, and between these three variables and investment climate variables, is that the extent of underutilization of labor by firms is strongly and positively related to firm productivity. Also, the more productive firms tend to overutilize capital more than the average, though not to the same extent that they underutilize labor.

Overall, our findings suggest that if labor market restrictions in states with "poorly functioning" labor markets were liberalized to the level of restrictions in states with better 
functioning labor markets, labor demand and wages would likely increase significantly in those states. Also such liberalization would likely increase productivity without significant increases in the demand for capital. This would occur both because our results suggest that an improvement in the functioning of labor markets would cause the more productive firms to increase their output disproportionately, and because firm productivity should increase as labor and capital employment move towards their efficient levels.

We also obtained a number of other more detailed findings. Firms which suffer more production losses due to electricity outages are less productive within their states and underutilize both labor and capital more than firms in states with less production losses due to electricity outages. Firms reporting more problems with corruption are shown to be the more productive firms in their state and they also exhibit relatively high underutilization of both factors of production. The relatively more productive firms within states are more likely to receive loans, suggesting that loan-granting institutions are able to select out the more productive firms. Finally, we find that states in which a disproportionate number of firms received loans are the states with less underutilization of both factors of production, particularly of capital. 


\section{References}

Ackerberg, D., Benkard, L., Berry, S., and Pakes, A. (2007) 'Econometric Tools for Analyzing Market Outcomes,' Handbook of Econometrics, Volume 6 Part 15.

Ahsan, A. and Pages, C. (2005). 'Helping or Hurting Workers? Assessing the Effects of De Jure and De Facto Labor Regulation in India,' mimeo, The World Bank.

Besley, T. and Burgess, R. (2004). 'Can Labor Regulation Hinder Economic Performance? Evidence from India,' Quarterly Journal of Economics 119, 91-134.

Fallon, P. and R. Lucas (1991). 'The Impact of Changes in Job Security Regulations in India and Zimbabwe,' World Bank Economic Review 5, 395-413.

Mengistae, T., Xu, C. and Yeung, B. (2006). 'China vs. India: A Microeconomic Look at Comparative Macroeconomic Performance,' mimeo, The World Bank.

Mundlak, Y. (1978). 'On The Pooling of Time Series and Cross Section Data,' Econometrica, 46, pp.69-85.

OECD (2007). OECD Employment Outlook.

Olley, G. and Pakes, A. (1996). 'The Dynamics of Productivity in the Telecommunications Equipment Industry,' Econometrica 64, 1263-1297.

The World Bank (2004) Improving the Investment Climate in India.

The World Bank (2006) India's Employment Challenge: Creating Jobs, Helping Workers. The World Bank (2007) Doing Business in South Asia. 


\section{Table 1. Industry and Manufacturing Share of Employment and GDP across Countries}

\begin{tabular}{lcccc}
\hline & $\begin{array}{c}\text { Employment in } \\
\text { Industry as \% } \\
\text { Total } \\
\text { Employment in } \\
2000\end{array}$ & $\begin{array}{c}\text { Value Added in } \\
\text { Industry as \% } \\
\text { of GDP in 2000 }\end{array}$ & $\begin{array}{c}\text { Value Added in } \\
\text { Manufacturing as } \\
\% \text { of GDP in } \\
2000\end{array}$ & $\begin{array}{c}2002 \text { GDP per } \\
\text { capita (in 2000 } \\
\text { USD) }\end{array}$ \\
\hline India & 18.2 & 26.3 & 15.6 & 480 \\
Brazil & 19.3 & 28.0 & 17.1 & 3473 \\
China & 23.0 & 45.9 & 34.7 & 1106 \\
Indonesia & 17.3 & 45.9 & 27.7 & 844 \\
Pakistan & 18.0 & 22.6 & 14.8 & 532 \\
Vietnam & 12.4 & 36.7 & 18.6 & 444 \\
Low-Income Countries & 12.3 & 26.6 & 14.1 & \\
Lower-Middle Income Countries & 18.5 & 38.3 & 24.2 & \\
\hline
\end{tabular}

Source: World Development Indicators 2005.

Notes: Industry includes manufacturing, but also mining and quarrying (including oil production), construction, and public utilities (electricity, gas, and water). Lower-income countries and lower-middle income countries are defined based on the World Bank classification.

\section{Table 2. Growth in Sectoral Value-Added across Countries}

\begin{tabular}{lcccccc}
\hline & $\begin{array}{c}\text { Growth in Value Added in } \\
\text { Manufacturing }\end{array}$ & \multicolumn{2}{c}{$\begin{array}{c}\text { Growth in Value Added in } \\
\text { Agriculture }\end{array}$} & \multicolumn{2}{c}{$\begin{array}{c}\text { Growth in Value Added in } \\
\text { Services }\end{array}$} \\
& $1995-2000$ & $2000-2005$ & $1995-2000$ & $2000-2005$ & $1995-2000$ & $2000-2005$ \\
\hline India & $28.1 \%$ & $38.4 \%$ & $13.7 \%$ & $14.9 \%$ & $48.4 \%$ & $50.3 \%$ \\
Brazil & $5.7 \%$ & $5.6 \%$ & $17.3 \%$ & $23.7 \%$ & $26.5 \%$ & $31.8 \%$ \\
China & $57.6 \%$ & $67.4 \%$ & $18.5 \%$ & $21.2 \%$ & $57.3 \%$ & $61.2 \%$ \\
Indonesia & $14.6 \%$ & $27.5 \%$ & $7.0 \%$ & $17.3 \%$ & $-2.4 \%$ & $35.7 \%$ \\
Pakistan & $17.1 \%$ & $56.6 \%$ & $26.5 \%$ & $12.0 \%$ & $20.9 \%$ & $29.9 \%$ \\
Vietnam & $70.3 \%$ & $73.8 \%$ & $24.2 \%$ & $20.7 \%$ & $31.9 \%$ & $40.0 \%$ \\
\hline
\end{tabular}

Source: World Development Indicators 2005.

Note: The table shows for each sector growth rates in total value-added (in constant local currency units) between year $\mathrm{t}$ and year $\mathrm{t}+5$. 
Table 3. Sales Generating Function Estimates

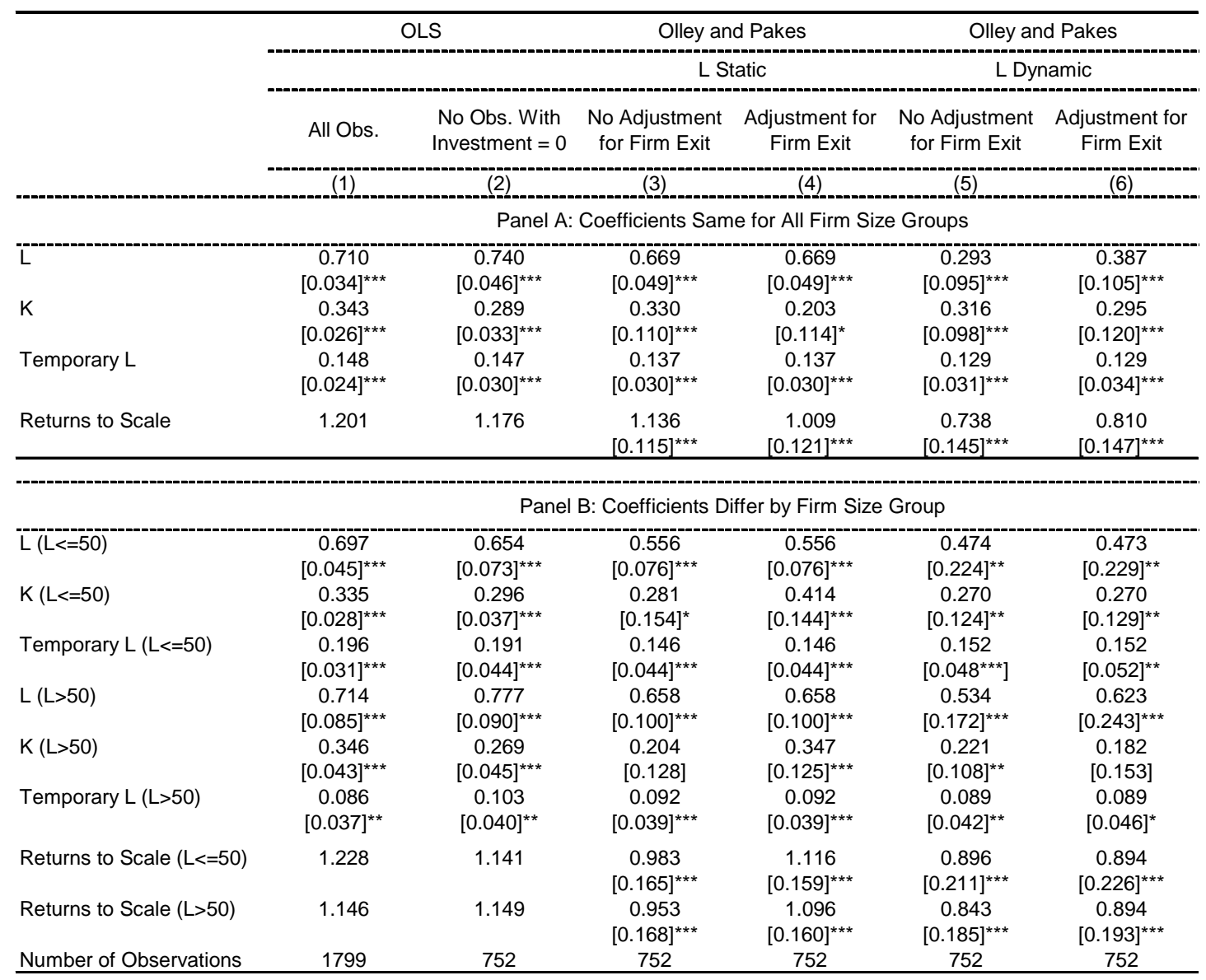

Notes: Bootstrapped standard errors in parentheses. ***.**, and * indicate statistical significance at a $1 \%, 5 \%$, and $10 \%$ confidence levels, respectively. The sample includes all firms with replacement capital and investment data in the initial survey (covering 2001). When labor is dynamic, it is treated as another state variable (like capital in the Olley and Pakes framework), otherwise it is assumed to be optimized out in each period. All specifications control for industry dummies and period dummies at all estimation stages. 
Table 4. Average Cost of Labor

\begin{tabular}{lccc}
\hline & \multicolumn{3}{c}{ Average Wages and Benefits per Worker } \\
& Year & $\begin{array}{c}\text { From Annual Survey } \\
\text { of Industries }\end{array}$ & $\begin{array}{c}\text { From Investment } \\
\text { Climate Surveys }\end{array}$ \\
\hline Andra Pradesh & 2001 & 47.6 & 60.2 \\
Delhi & 2004 & 55.8 & 59.4 \\
& 2001 & 90.7 & 45.6 \\
Gujarat & 2004 & 109.0 & 91.7 \\
Haryana & 2001 & 87.6 & 53.5 \\
& 2004 & 108.1 & 48.0 \\
Karnakata & 2001 & 99.3 & 56.1 \\
Kerala & 2004 & 122.9 & 106.1 \\
& 2001 & 87.1 & 70.8 \\
Madhya Pradesh & 2004 & 104.4 & 29.7 \\
& 2001 & 55.9 & 35.7 \\
Maharastra & 2004 & 57.9 & 33.8 \\
Punjab & 2001 & 89.8 & 51.0 \\
& 2004 & 95.9 & 16.9 \\
Tamil Nadu & 2001 & 129.9 & 80.9 \\
Uttar Pradesh & 2004 & 151.9 & 29.8 \\
West Bengal & 2001 & 59.9 & 47.6 \\
& 2004 & 71.2 & 64.2 \\
& 2001 & 63.0 & 62.0 \\
& 2004 & 70.8 & 57.4 \\
& 2001 & 77.8 & 49.3 \\
& 2004 & 85.3 & 65.4 \\
& 2001 & 84.6 & 50.1 \\
& 2004 & 92.6 & 80.1 \\
\hline
\end{tabular}

Sources: Annual Survey of Industries and Investment Climate Surveys for India. Note: Average wages and benefits are expressed in thousands of rupees per year. 
Table 5. Average Cost of Capital

\begin{tabular}{|c|c|c|c|c|c|}
\hline & \multirow[b]{3}{*}{ Year } & \multicolumn{4}{|c|}{ Average Cost of Capital } \\
\hline & & \multicolumn{2}{|c|}{ From Annual Survey of Industries } & \multicolumn{2}{|c|}{ From Investment Climate Surveys } \\
\hline & & $\begin{array}{c}\text { Average Interest } \\
\text { Rate }\end{array}$ & $\begin{array}{c}\text { Average } \\
\text { Depreciation } \\
\text { Rate }\end{array}$ & $\begin{array}{c}\text { Average Interest } \\
\text { Rate }\end{array}$ & $\begin{array}{c}\text { Median Interest } \\
\text { Rate }\end{array}$ \\
\hline \multirow[t]{2}{*}{ Andra Pradesh } & 2001 & $15.4 \%$ & $8.3 \%$ & $13.4 \%$ & $14.0 \%$ \\
\hline & 2004 & $14.0 \%$ & $9.4 \%$ & $9.0 \%$ & $9.3 \%$ \\
\hline \multirow[t]{2}{*}{ Delhi } & 2001 & $17.1 \%$ & $13.3 \%$ & $11.1 \%$ & $10.0 \%$ \\
\hline & 2004 & $11.5 \%$ & $15.0 \%$ & $17.9 \%$ & $14.0 \%$ \\
\hline \multirow[t]{2}{*}{ Gujarat } & 2001 & $16.4 \%$ & $8.5 \%$ & $13.8 \%$ & $14.0 \%$ \\
\hline & 2004 & $10.7 \%$ & $9.4 \%$ & $16.8 \%$ & $10.0 \%$ \\
\hline \multirow[t]{2}{*}{ Haryana } & 2001 & $19.2 \%$ & $11.0 \%$ & $13.0 \%$ & $14.0 \%$ \\
\hline & 2004 & $16.5 \%$ & $13.5 \%$ & $12.2 \%$ & $12.3 \%$ \\
\hline \multirow[t]{2}{*}{ Karnakata } & 2001 & $12.3 \%$ & $7.3 \%$ & $12.9 \%$ & $12.5 \%$ \\
\hline & 2004 & $11.0 \%$ & $9.0 \%$ & $12.2 \%$ & $11.8 \%$ \\
\hline \multirow[t]{2}{*}{ Kerala } & 2001 & $15.3 \%$ & $9.2 \%$ & $17.0 \%$ & $13.5 \%$ \\
\hline & 2004 & $13.8 \%$ & $9.9 \%$ & $11.1 \%$ & $10.5 \%$ \\
\hline \multirow[t]{2}{*}{ Madhya Pradesh } & 2001 & $14.9 \%$ & $8.6 \%$ & $13.4 \%$ & $12.5 \%$ \\
\hline & 2004 & $13.3 \%$ & $9.5 \%$ & $10.1 \%$ & $10.0 \%$ \\
\hline \multirow[t]{2}{*}{ Maharastra } & 2001 & $18.4 \%$ & $9.5 \%$ & $13.6 \%$ & $14.0 \%$ \\
\hline & 2004 & $13.0 \%$ & $9.1 \%$ & $10.2 \%$ & $10.0 \%$ \\
\hline \multirow[t]{2}{*}{ Punjab } & 2001 & $21.8 \%$ & $11.3 \%$ & $13.3 \%$ & $14.0 \%$ \\
\hline & 2004 & $13.7 \%$ & $11.8 \%$ & $22.1 \%$ & $14.0 \%$ \\
\hline \multirow[t]{2}{*}{ Tamil Nadu } & 2001 & $19.9 \%$ & $10.0 \%$ & $11.8 \%$ & $12.0 \%$ \\
\hline & 2004 & $12.2 \%$ & $10.2 \%$ & $10.9 \%$ & $11.0 \%$ \\
\hline \multirow[t]{2}{*}{ Uttar Pradesh } & 2001 & $16.0 \%$ & $8.1 \%$ & $13.0 \%$ & $14.0 \%$ \\
\hline & 2004 & $12.0 \%$ & $10.0 \%$ & $18.4 \%$ & $12.0 \%$ \\
\hline \multirow{2}{*}{ West Bengal } & 2001 & $15.6 \%$ & $8.2 \%$ & $13.3 \%$ & $14.0 \%$ \\
\hline & 2004 & $8.9 \%$ & $8.6 \%$ & $9.9 \%$ & $10.0 \%$ \\
\hline
\end{tabular}

Sources: Annual Survey of Industries and Investment Climate Surveys for India.

Table 6. Underutilization of Labor and GDP per Capita by State

\begin{tabular}{lcc}
\hline & $\begin{array}{c}\text { Underutilization } \\
\text { of Labor } \\
\text { Average over } 2001 \text { and } 2004\end{array}$ & $\begin{array}{c}\text { Level of GDP } \\
\text { per Capita }\end{array}$ \\
\hline Uttar Pradesh & 8.60 & 6721 \\
Madhya Pradesh & 0.37 & 8694 \\
West Bengal & 8.10 & 11825 \\
Andra Pradesh & 6.47 & 12290 \\
Kerala & 1.77 & 13157 \\
Karnakata & 1.47 & 13793 \\
Tamil Nadu & 3.35 & 14798 \\
Gujarat & 1.58 & 17211 \\
Haryana & 0.51 & 17063 \\
Maharastra & 1.30 & 17698 \\
Punjab & 0.45 & 17697 \\
Delhi & 0.22 & 27864 \\
\hline
\end{tabular}

Sources: Authors' calculations based on the Investment Climate Surveys for India and indiastat.com. Note: Per capita GDP is expressed in billions of constant 1993-1994 rupees. 
Table 7. Change in Underutilization of Labor and in GDP per Capita by State

\begin{tabular}{lcc}
\hline & $\begin{array}{c}\text { Change in } \\
\text { Underutilization } \\
\text { of Labor between } \\
\text { 2001 and 2004 }\end{array}$ & $\begin{array}{c}\text { Change in Level } \\
\text { of GDP per } \\
\text { Capita between } \\
2001 \text { and 2004 }\end{array}$ \\
\hline Uttar Pradesh & $304.2 \%$ & $6.8 \%$ \\
Madhya Pradesh & $-57.5 \%$ & $11.3 \%$ \\
West Bengal & $-1182.7 \%$ & $20.1 \%$ \\
Andra Pradesh & $-187.2 \%$ & $14.8 \%$ \\
Kerala & $-270.3 \%$ & $19.1 \%$ \\
Karnakata & $-69.9 \%$ & $7.0 \%$ \\
Tamil Nadu & $80.1 \%$ & $1.3 \%$ \\
Gujarat & $-298.0 \%$ & $27.1 \%$ \\
Haryana & $58.2 \%$ & $13.3 \%$ \\
Maharastra & $8.3 \%$ & $17.1 \%$ \\
Punjab & $-13.6 \%$ & $7.8 \%$ \\
Delhi & $43.8 \%$ & $10.3 \%$ \\
\hline
\end{tabular}

Sources: Authors' calculations based on the Investment Climate Surveys for India and indiastat.com.

Table 8. Overutilization of Capital and GDP per Capita by State

\begin{tabular}{lcc}
\hline & $\begin{array}{c}\text { Overutilization } \\
\text { of Capital } \\
\text { Average over 2001 and 2004 }\end{array}$ & $\begin{array}{c}\text { Level of GDP } \\
\text { per Capita }\end{array}$ \\
\hline Uttar Pradesh & -0.40 & 6721 \\
Madhya Pradesh & -0.80 & 8694 \\
West Bengal & -0.72 & 11825 \\
Andra Pradesh & -0.88 & 12290 \\
Kerala & -0.63 & 13157 \\
Karnakata & -0.92 & 13793 \\
Tamil Nadu & -0.66 & 14798 \\
Gujarat & -0.86 & 17211 \\
Haryana & -0.67 & 17063 \\
Maharastra & -0.66 & 17698 \\
Punjab & -0.69 & 17697 \\
Delhi & -0.59 & 27864 \\
\hline
\end{tabular}

Sources: Authors' calculations based on the Investment Climate Surveys for India and indiastat.com. 


\section{Table 9. Average TFP and GDP per Capita by State}

\begin{tabular}{lccc}
\hline & $\begin{array}{c}\text { Weighted } \\
\text { Average TFP }\end{array}$ & $\begin{array}{c}\text { Unweighted } \\
\text { Average TFP } \\
\text { Average over 2001 and 2004 }\end{array}$ & $\begin{array}{c}\text { Level of GDP } \\
\text { per Capita }\end{array}$ \\
\hline Uttar Pradesh & 139.41 & 47.98 & 6721 \\
Madhya Pradesh & 207.37 & 63.06 & 8694 \\
West Bengal & 518.40 & 81.68 & 11825 \\
Andra Pradesh & 66.75 & 45.72 & 12290 \\
Kerala & 74.83 & 36.35 & 13157 \\
Karnakata & 41.30 & 33.08 & 13793 \\
Tamil Nadu & 81.45 & 61.26 & 14798 \\
Gujarat & 127.08 & 40.71 & 17211 \\
Haryana & 68.98 & 63.62 & 17063 \\
Maharastra & 78.88 & 40.39 & 17698 \\
Punjab & 32.23 & 32.11 & 17697 \\
Delhi & 33.41 & 29.41 & 27864 \\
\hline
\end{tabular}

Sources: Authors' calculations based on the Investment Climate Surveys for India and indiastat.com.

Note: In calculating weighted average TFP, the weights are given by each firm's share in total sales for its state.

Table 10. Underutilization of Labor, Underutilization of Capital, and Productivity

\begin{tabular}{|c|c|c|c|}
\hline & \multicolumn{3}{|c|}{ Dependent Variable is: } \\
\hline & $\begin{array}{l}\text { Under } \\
\text { utilization of } \\
\text { Labor }\end{array}$ & $\begin{array}{l}\text { Under } \\
\text { utilization of } \\
\text { Capital }\end{array}$ & TFP \\
\hline & (1) & (2) & (3) \\
\hline Share of Temporary Labor in Total Labor - Avg. State Year & $\begin{array}{c}6.649 \\
{[17.428]}\end{array}$ & $\begin{array}{c}15.814 \\
{[30.086]}\end{array}$ & $\begin{array}{c}0.109 \\
{[0.129]}\end{array}$ \\
\hline Share of Workforce Unionized & $\begin{array}{c}23.276 \\
{[21.952]}\end{array}$ & $\begin{array}{l}-23.746 \\
{[37.897]}\end{array}$ & $\begin{array}{c}1.275 \\
{[0.162]^{\star \star \star}}\end{array}$ \\
\hline Share of Workforce Unionized - Avg. State Year & $\begin{array}{c}280.012 \\
{[129.199]^{\star *}}\end{array}$ & $\begin{array}{c}688.058 \\
{[223.043]^{\star * *}}\end{array}$ & $\begin{array}{c}4.249 \\
{[0.956]^{\star * \star}}\end{array}$ \\
\hline Dummy for Firm with Loan & $\begin{array}{c}15.236 \\
{[8.883]^{*}}\end{array}$ & $\begin{array}{c}-7.157 \\
{[15.335]}\end{array}$ & $\begin{array}{c}0.292 \\
{[0.066]^{\star \star \star}}\end{array}$ \\
\hline Share of Firms with Loan - Avg. State Year & $\begin{array}{c}-77.554 \\
{[34.608]^{\star *}}\end{array}$ & $\begin{array}{c}-181.481 \\
{[59.746]^{\star \star \star}}\end{array}$ & $\begin{array}{c}-1.353 \\
{[0.256]^{\star * *}}\end{array}$ \\
\hline Production Losses Due to Outages & $\begin{array}{l}-14.469 \\
{[45.466]}\end{array}$ & $\begin{array}{c}12.919 \\
{[78.490]}\end{array}$ & $\begin{array}{c}-0.6 \\
{[0.336]^{*}}\end{array}$ \\
\hline Production Losses Due to Outages - Avg. State Year & $\begin{array}{c}343.424 \\
{[200.498]^{\star}}\end{array}$ & $\begin{array}{c}961.361 \\
{[346.130]^{\star * *}}\end{array}$ & $\begin{array}{c}3.68 \\
{[1.483]^{\star *}}\end{array}$ \\
\hline Corruption in Inspections & $\begin{array}{c}18.387 \\
{[11.099]^{*}}\end{array}$ & $\begin{array}{c}35.186 \\
{[19.160]^{*}}\end{array}$ & $\begin{array}{c}0.231 \\
{[0.082]^{\star * \star}}\end{array}$ \\
\hline Corruption in inspections - Avg. State Year & $\begin{array}{c}-57.94 \\
{[34.661]^{\star}}\end{array}$ & $\begin{array}{c}-125.275 \\
{[59.837]^{\star *}}\end{array}$ & $\begin{array}{c}0.492 \\
{[0.256]^{*}}\end{array}$ \\
\hline $\begin{array}{l}\text { Number of Observations } \\
\text { "R-squared" }\end{array}$ & $\begin{array}{c}1500 \\
0.0136\end{array}$ & $\begin{array}{c}1500 \\
0.0181\end{array}$ & $\begin{array}{l}1500 \\
0.0966\end{array}$ \\
\hline
\end{tabular}




\begin{tabular}{lccc}
\hline & \multicolumn{3}{c}{ Variance of: } \\
& $\begin{array}{c}\text { Underut. } \\
\text { of Labor }\end{array}$ & $\begin{array}{c}\text { Underut. } \\
\text { of Capital }\end{array}$ & TFP \\
Total & 25351.1 & 75899.4 & 1.51 \\
Within & 24953.7 & 75261.5 & 1.47 \\
Between & 635.4 & 604.8 & 0.05 \\
\hline \multicolumn{4}{c}{ Variance of Residuals of } \\
& \multicolumn{3}{c}{ Equation for: } \\
Underut. & Underut. & TFP \\
Total & of Labor & of Capital \\
Within & 25005.8 & 74524.4 & 1.37 \\
Between & 24862.6 & 74321.1 & 1.36 \\
\hline & 283.4 & 214.2 & 0.01 \\
\hline
\end{tabular}

\begin{tabular}{lrr}
\hline \multicolumn{1}{c}{$\begin{array}{c}\text { Covariance between } \\
\text { Residuals of Equation for: }\end{array}$} & $\begin{array}{c}\text { Underut. } \\
\text { of Capital }\end{array}$ & \multicolumn{1}{c}{ TFP } \\
Underut. of Labor & -846037 & 69433 \\
Total & -802619 & 70143 \\
Within & -43418 & -710 \\
Between & & \\
Underut. of Capital & & -24250 \\
Total & & -24311 \\
Within & & 61 \\
Between & & \\
\hline & & \\
$\quad$ Correlation between & & \\
Residuals of Equation for: & Underut. \\
& TFP Capital & \\
Underut. of Labor & & \\
Total & -0.0131 & $0.250^{\star * *}$ \\
Within & -0.0124 & $0.253^{\star * *}$ \\
Between & -0.0007 & -0.002561 \\
Underut. of Capital & & \\
Total & & $-0.051^{*}$ \\
Within & & $-0.051^{*}$ \\
Between & & 0.0001 \\
\hline
\end{tabular}

Notes: Seemingly unrelated regressions estimation used. Standard errors in parentheses. ***.**, and * indicate statistical significance at a $1 \%, 5 \%$, and $10 \%$ confidence levels, respectively. The regressions include year fixed effects. 


\section{Figure 1. Percentage of Firms by Size Group across Countries}

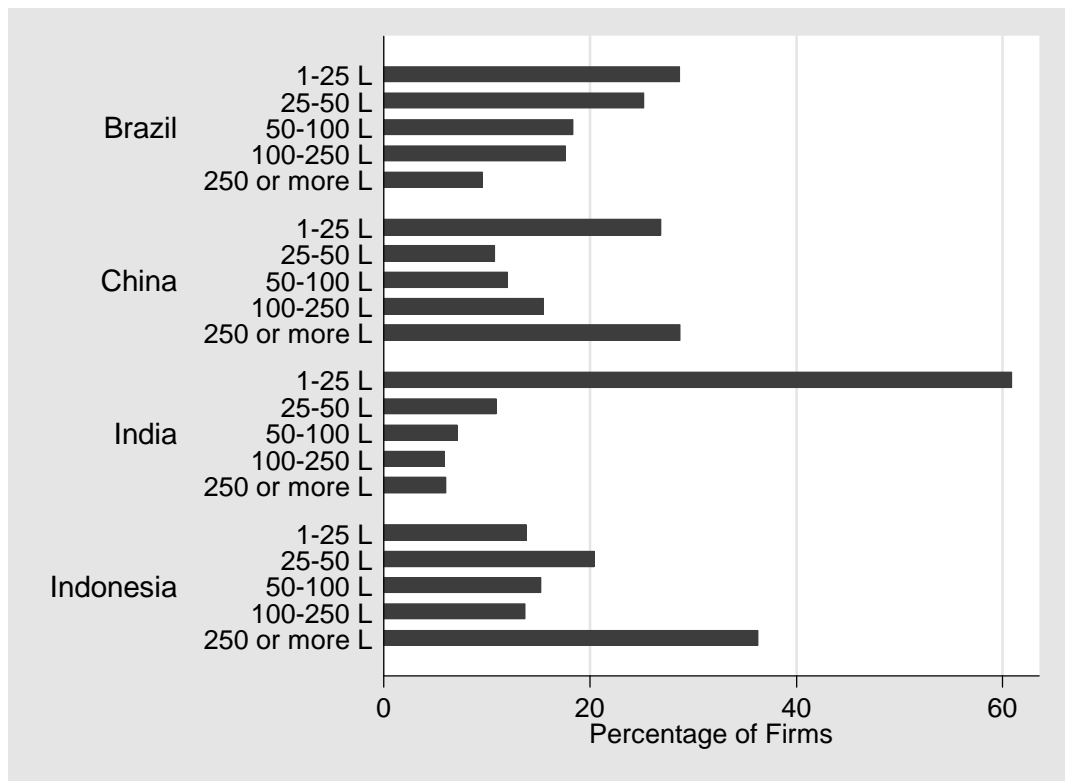

Source: Investment Climate Surveys for Brazil, China, India, and Indonesia.

Figure 2. Underutilization of Labor by Size Group

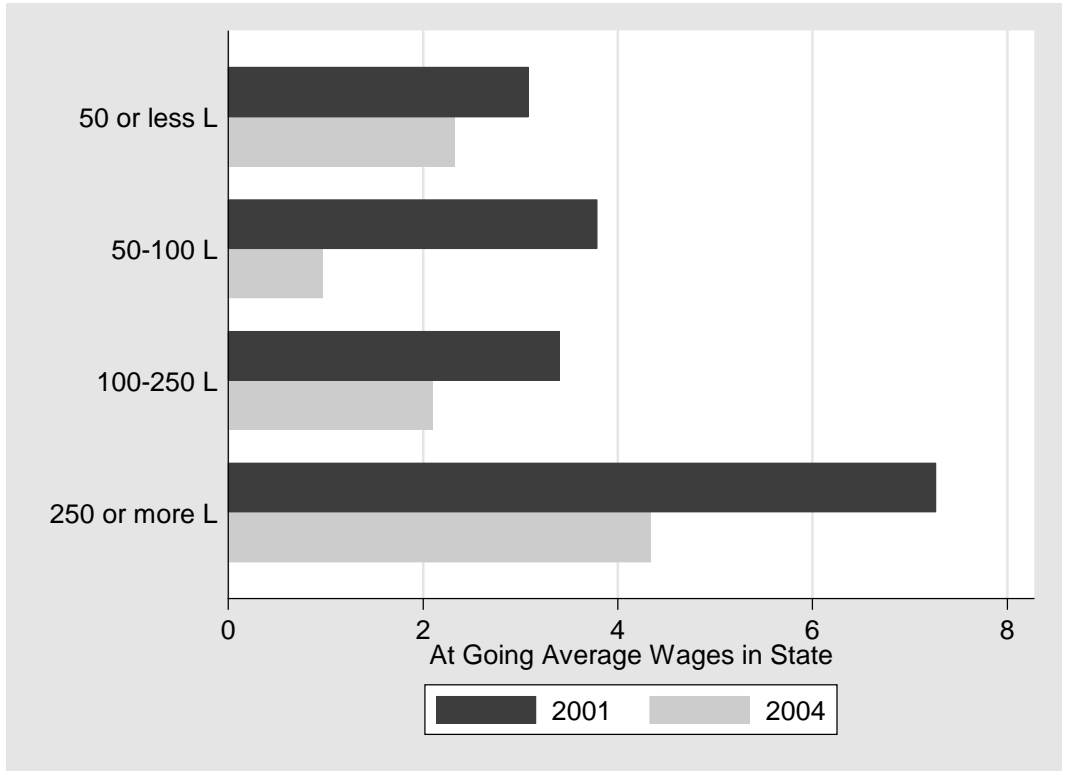

Source: Authors' calculations based on the Investment Climate Surveys for India.

Notes: In the Y-axis L stands for employees. The figure shows for each year the weighted sum of the measured underutilization of labor across firms, where weights are given by each firm's share in total employment for its size group. 
Figure 3. Change in Underutilization of Labor and in GDP Per Capita across States

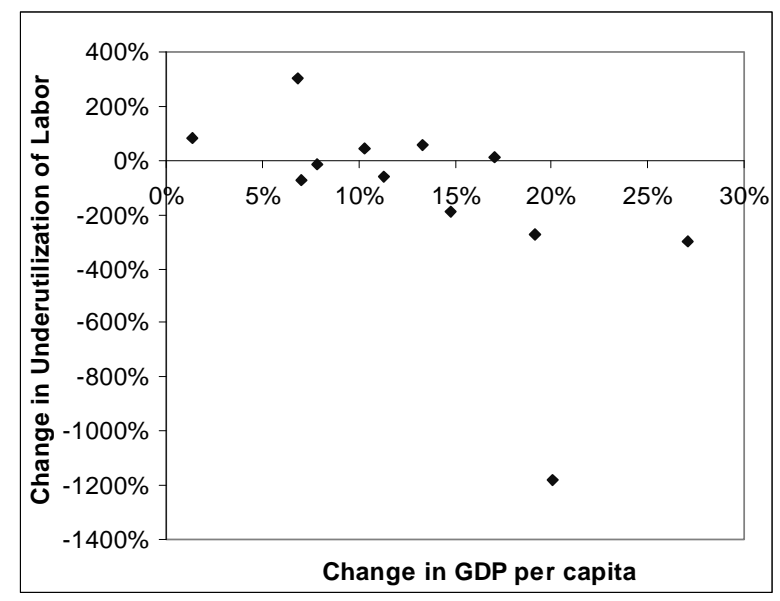

Source: Authors' calculations based on the Investment Climate Surveys for India.

Note: Each dot in the figure represents one Indian state and shows the change between 2001 and 2004 in GDP per capita and in the underutilization of labor.

\section{Figure 4. Overutilization of Capital by Size Group}

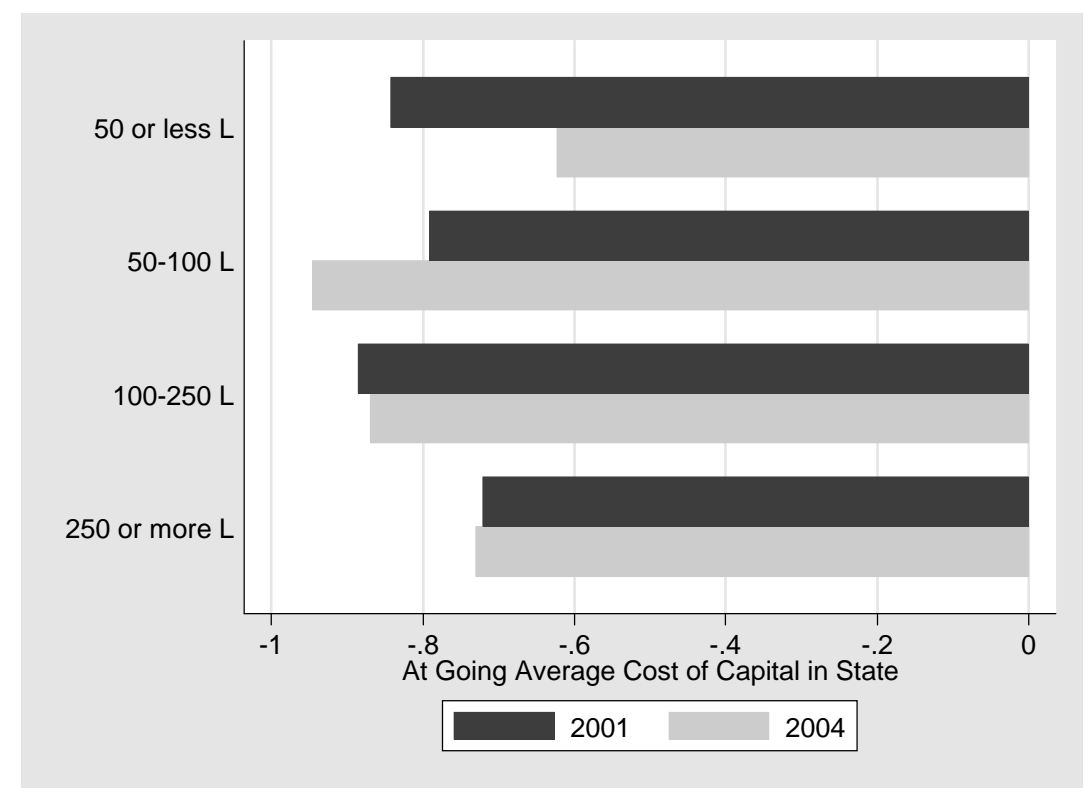

Source: Authors' calculations based on the Investment Climate Surveys for India.

Notes: In the Y-axis L stands for employees. The figure shows for each year the weighted sum of the measured overutilization of capital across firms, where weights are given by each firm's share in total capital for its size group. 


\section{Figure 5. Weighted Average TFP and GDP Per Capita across States}

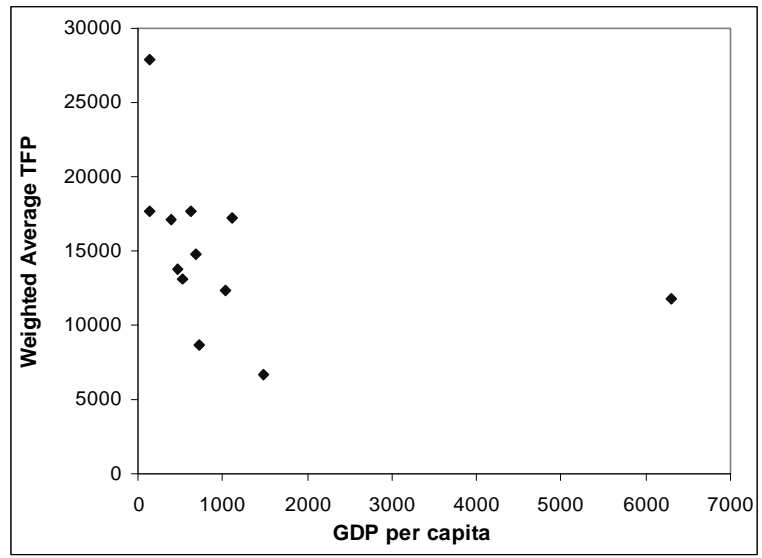

Source: Authors' calculations based on the Investment Climate Surveys for India.

Note: Each dot in the figure represents one Indian state and shows the average across 2001 and 2004 of GDP per capita and of weighted average TFP, where weights are given by each firm's share in total sales for its state.

Figure 6. Unweighted Average TFP and GDP Per Capita across States

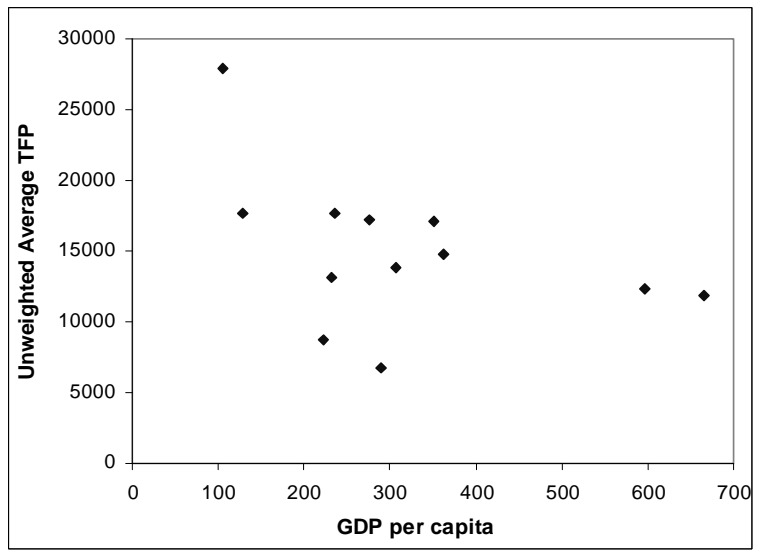

Source: Authors' calculations based on the Investment Climate Surveys for India.

Note: Each dot in the figure represents one Indian state and shows the average across 2001 and 2004 of GDP per capita and of unweighted average TFP. 


\section{Appendix}

\section{A. Investment Climate Surveys Data and ASI Data}

The sample used for the Investment Climate Survey (also known as Firm Analysis and Competitiveness Survey) of India in the 2002 round was designed to cover firms in the top 40 industrial cities in India (located in 12 states) that account for more than $90 \%$ of India's industrial GDP. In the 2005 round, the survey covered some additional states but we exclude them from our analysis that requires information in both 2001 and 2004. See World Bank (2004) and Mengistae, Xu, and Yeung (2006) for more details on the survey and the data.

The measure of output used in our production function estimation is firm value added defined as total sales minus purchases of raw materials minus consumption of energy minus other costs (e.g. overhead expenses, selling and general administration expenses, design department). The measure of capital for 2001 is the sum of the firm reported value of (i) replacing all machinery and equipment at the end of 2001 and (ii) replacing all business premises or leasehold at the end of 2001. Since data on replacement cost for capital was not collected in the 2005 survey round, we constructed the measure of capital for 2004 based on replacement value in 2001 and on the change in book value of fixed assets (machinery and equipment plus land, buildings and leasehold improvement) between 2001 and 2004. As mentioned in the main text, our measure of labor is the number of permanent workers (all paid workers that are not temporary) and we also consider a measure of temporary labor to equal consisting of all (paid) short term (i.e. for less than a year) workers with no guarantee of renewal of employment contract.

Appendix Tables 1 and 3-4 show the distribution of sample firms considered for our analysis of the underutilization of factors across size groups, states, and industries.

In Table 3 we show a measure of compensation to workers from the Investment Climate Surveys calculated as the average in each state of firms' total compensation paid to workers (including wages, salaries, and benefits) divided by the firms' number of permanent workers. In order to compute underutilization of labor across firms, we use the average wage and benefits across Indian states shown in Table 3 taken from the Annual Survey of Industries. This survey is conducted annually and covers all manufacturing factories employing 10 or more workers using power and those employing 20 or more workers without using power across all Indian states (more information can be found at www.mospi.nic.in). Our measure of average wages and benefits is total emoluments obtained as the sum of the items i) ii) and iii) below, divided by the total number of manufacturing workers in each state and year.

i) Wages and salaries: defined to include all remuneration in monetary terms and also payable more or less regularly in each pay period to workers as compensation for work done during the accounting year. This includes (a) direct wages and salary (i.e., basic wages/salaries, payment of overtime, dearness, compensatory allowance, house rent and other allowances), (b) remuneration for the period not worked (i.e., basic wages, salaries and allowances payable for leave period, paid holiday, lay-off payments and compensation for unemployment, if not paid from sources other than employers), (c) bonuses and ex-gratia payment paid both at regular and less frequent intervals (i.e., incentive bonuses, good attendance bonuses, productive bonuses, profit sharing bonuses, 
festival or year-end bonuses, etc.). The wages are expressed in terms of gross value i.e., before deduction for fines, damages, taxes, provident fund, employee's state insurance contribution.

ii) Employers' contribution to provident fund and other funds: include old age benefits like provident fund, pension, gratuity, etc. and employers contribution towards other social security charges such as employees state insurance, compensation for work injuries and occupational diseases, provident fund-linked insurance, retrenchment and lay-off benefits.

iii) Workmen and staff welfare expenses: include group benefits like direct expenditure on maternity, day-care, canteen facilities, educational, cultural and recreational facilities, and grants to trade unions, co-operative stores meant for employees.

In Table 4 we show a measure of cost of capital from the Investment Climate Surveys calculated as the average in each state of the interest rate on loans taken up by firms since 1992. In order to compute underutilization of capital across firms, we use the average cost of capital across Indian states shown in Table 4 taken from the Annual Survey of Industries.

Our measure of the average cost of capital is obtained as the sum of the average interest rate obtained as the ratio of the items i) to ii) below and the average depreciation rate obtained as the ratio of the items iii) to iv) below.

i) Interest paid

ii) Outstanding loans: represent all loans (short term or long term, interest bearing or not) outstanding according to the books of the factory as on the closing day of the accounting year.

iii) Depreciation: is consumption of fixed capital due to wear \& tear and obsolescence during the accounting year and is taken as provided by the factory owner or is estimated on the basis of cost of installation and working life of the fixed assets.

iv) Fixed capital: represents the depreciated value of fixed assets owned by the factory as on the closing day of the accounting year. Fixed assets are those that have a normal productive life of more than one year. Fixed capital includes land including leasehold land, buildings, plant \& machinery, furniture and fixtures, transport equipment, water system and roadways and other fixed assets such as hospitals, schools, etc. used for the benefit of the factory personnel.

\section{Appendix B. Underutilization of Labor and Capital in Sri Lanka}

This appendix briefly examines the underutilization of labor and capital in Sri Lanka, another country characterized by restrictive labor market regulations, as discussed in World Bank (2007). Note an important difference in the restrictiveness of labor market regulations in India versus Sri Lanka. In India, the restrictiveness lies in the difficulty of firing workers. However, Indian workers that are fired are entitled to low severance payments by international standards (see Ahsan and Pages, 2005). In Sri Lanka, the restrictiveness lies in the very high severance payments that fired workers are entitled to.

Our approach is similar to that used for India: i.e., we construct underutilization of labor at current wage rates and underutilization of capital at current capital costs. However, we modify the approach given Sri Lanka's much smaller size and different 
regulatory environment. Sri Lanka is a unitary state and its provinces do not have legislative power on labor market regulations as the Indian states do. Thus, we consider Sri Lanka as a single labor market and a single capital market, not examining differences across provinces. Our analysis uses data from the World Bank Investment Climate Survey conducted in Sri Lanka in 2004. This dataset suffers from some caveats relative to India' s dataset. First, the Sri Lanka data is from a single survey round rather than two survey rounds. Thus, we are forced to use retrospective data for the accounting variables which as we mentioned in Section 2, can suffer from measurement problems. Second, the measure of capital used for firms in Sri Lanka is book value of capital, since replacement value information was not collected. Third, since we do not have data from a Sri Lanka census source such as the Indian ASI, we use measures of average compensation per worker from the Investment Climate Survey, which may under- or over-estimate the true labor costs faced by firms in the manufacturing sector. Fourth, some numerical problems constrain us to estimate the production function using the standard Olley and Pakes (1996) technique i.e., allowing labor to be adjustable in the short-run, in contrast to India where labor was assumed to be fixed in the short-run. However, our production function estimation allows for different coefficients for firms employing more than 50 workers and for firms employing less than 50 workers, as in the case of India. These caveats imply that the numbers below needs to be taken with a lot of caution, as they are only broadly indicative of the patterns of underutilization of factors. In particular, one should not compare the magnitudes of underutilization of factors across India and Sri Lanka since they are based on different data and on production function coefficients estimated using different techniques.

Our main finding is strong evidence of underutilization of labor across manufacturing firms in Sri Lanka. Overall we estimate underutilization of 1.1 times current manufacturing employment in 2003. Underutilization of labor is estimated to be positive for every size group of firms. We also calculated what the wage would have to be for firms' current employment to be "statically optimal" (i.e. the wage equal to a firm's marginal revenue product of labor at its current employment level). This wage averaged 2.1 times the current wage rates in 2003. As mentioned in Section 3, one has to be careful with the interpretation of these magnitudes. These figures do not imply that if there were no hiring and firing costs and constraints in Sri Lanka and firms were maximizing profits they would increase their employment by $110 \%$. If firms started increasing their employment, wages would rise, output would rise and the prices of the firms' outputs would fall (beyond what we are allowing for here). These two factors would moderate the actual equilibrium employment implications of reducing hiring and firing costs and constraints.

For manufacturing firms in Sri Lanka we also find evidence of overutilization of capital. Specifically, the overutilization of capital is on average equal to about a third of the capital stock in 2003. As in the case of India, this magnitude is much smaller than the corresponding magnitudes for the underutilization of labor. We also calculated what the cost of capital would have to be for the firm's current capital to be "statically optimal" (i.e. the cost of capital equal to the firm' s marginal revenue product of capital at its current capital level). On average across manufacturing firms this "statically optimal" cost of capital was $58 \%$ of the current cost of capital in 2003. While this number is not 
too far from $100 \%$ recall that the underutilization of labor resulted in a ratio of current wage rates to marginal productivity of labor of about $210 \%$.

Appendix Table 1: Distribution of Sample Firms across Size Groups

\begin{tabular}{lcc}
\hline & 2001 & 2004 \\
\hline 50 or less Employees & $81.4 \%$ & $78.4 \%$ \\
$50-100$ Employees & $7.2 \%$ & $9.4 \%$ \\
$100-250$ Employees & $5.6 \%$ & $6.7 \%$ \\
250 or more Employees & $5.8 \%$ & $5.6 \%$ \\
Number of Observations & 1296 & 721 \\
\hline
\end{tabular}

\section{Appendix Table 2: Share of Total Employment across Size Groups}

\begin{tabular}{lcc}
\hline & \multicolumn{2}{c}{$\begin{array}{c}\text { Distribution of Total } \\
\text { Employment across Firm Size } \\
\text { Groups }\end{array}$} \\
& 2001 & 2004 \\
\hline 50 or less Employees & $16.9 \%$ & $16.6 \%$ \\
$50-100$ Employees & $7.3 \%$ & $8.8 \%$ \\
$100-250$ Employees & $12.3 \%$ & $15.4 \%$ \\
250 or more Employees & $63.5 \%$ & $59.1 \%$ \\
\hline
\end{tabular}

\section{Appendix Table 3: Distribution of Sample Firms across States}

\begin{tabular}{lcc}
\hline & 2001 & 2004 \\
\hline Gujarat & $9.7 \%$ & $15.0 \%$ \\
Karnakata & $11.1 \%$ & $3.5 \%$ \\
West Bengal & $9.2 \%$ & $4.3 \%$ \\
Punjab & $9.0 \%$ & $10.8 \%$ \\
Tamil Nadu & $9.0 \%$ & $9.2 \%$ \\
Kerala & $3.6 \%$ & $2.1 \%$ \\
Delhi & $5.9 \%$ & $6.4 \%$ \\
Andra Pradesh & $7.6 \%$ & $6.7 \%$ \\
Uttar Pradesh & $10.0 \%$ & $11.4 \%$ \\
Maharastra & $10.8 \%$ & $12.3 \%$ \\
Haryana & $6.3 \%$ & $6.9 \%$ \\
Madhya Pradesh & $7.7 \%$ & $11.5 \%$ \\
Number of Observations & 1296 & 721 \\
\hline
\end{tabular}




\section{Appendix Table 4: Distribution of Sample Firms across Industries}

\begin{tabular}{lcc}
\hline & 2001 & 2004 \\
\hline Textiles & $12.2 \%$ & $8.5 \%$ \\
Garments and Leather & $18.7 \%$ & $11.9 \%$ \\
Metals and Machinery & $8.8 \%$ & $9.2 \%$ \\
Electronics & $16.4 \%$ & $16.6 \%$ \\
Chemicals and Pharmaceuticals & $18.6 \%$ & $21.2 \%$ \\
Transport Equipment & $15.7 \%$ & $21.5 \%$ \\
Food & $9.7 \%$ & $11.1 \%$ \\
Number of Observations & 1296 & 721 \\
\hline
\end{tabular}

\section{Appendix Table 5: Definition of Variables Used in System of Equations}

\begin{tabular}{ll}
\hline \multicolumn{1}{c}{ Variable } & \multicolumn{1}{c}{ Definition } \\
\hline \hline Share of Workforce Unionized & Percentage of the firm's workforce that is unionized. \\
\hline Dummy for Firm with Loan & $\begin{array}{l}\text { Dummy variable equal to 1 if the firm has a bank loan or overdraft from a financial } \\
\text { institution. }\end{array}$ \\
\hline Production Losses Due to Outages & $\begin{array}{l}\text { Percentage of sales lost due to electricity interruptions including lost production time } \\
\text { from the outage, time needed to reset machines, and production and sales lost due to } \\
\text { processes being interrupted. }\end{array}$ \\
\hline 'Corruption in Inspections & $\begin{array}{l}\text { Dummy variable equal to 1 if the firm reports that a gift or an informal payment was } \\
\text { expected or requested during inspections from the tax inspectorate, labor, fire and } \\
\text { building safety, sanitation/epidemiology, police, environmental agencies. }\end{array}$ \\
\hline
\end{tabular}

